\title{
Alkyd Printing Inks from Waste Frying Oil
}

\author{
Sivaphol PHUNPHOEM ${ }^{1}$, Onusa SARAVARI ${ }^{1}$ and Pitt SUPAPHOL ${ }^{2, *}$ \\ ${ }^{I}$ Department of Materials Science, Faculty of Science, Chulalongkorn University, \\ Bangkok 10330, Thailand \\ ${ }^{2}$ The Petroleum and Petrochemical College, Chulalongkorn University, Bangkok 10330, Thailand
}

('Corresponding author's e-mail: pitt.s@chula.ac.th)

Received: 25 March 2019, Revised: 21 July 2019, Accepted: 23 August 2019

\begin{abstract}
Alkyd-based printing ink vehicles were successfully prepared from waste frying oil. Three alkyd resins were synthesized using different ratios of phthalic anhydride. Properties of the 3 prepared resins were measured and compared with virgin oil alkyd resin and commercial alkyd resin. Viscosities of the obtained ink vehicles ranged from 8.6 to 34.9 poises. The vehicles were also completely compatible with carbon black for formulating black printing inks. Preliminary properties of the 3 formulated inks were evaluated and compared with black printing ink prepared from virgin oil alkyd and commercial alkyd. The formulated inks had satisfactory viscosity and tackiness as properties suitable for a variety of printing applications. The 3 synthesized inks had rub resistance values ranging from 4.61 to $5.75 \%$, slightly higher than the rub resistance of virgin oil alkyd ink and commercial alkyd ink. Particle fineness and water tolerance properties of the 3 formulated inks were comparable with virgin oil alkyd ink and commercial alkyd ink. Results suggested that waste frying oil has potential application as a raw material in the printing ink industry.
\end{abstract}

Keywords: Alkyd printing inks, Ink vehicles, Waste frying oil, Sustainable raw materials

\section{Introduction}

Unsustainable production systems due to the large increase in resource consumption and waste production are present day environmental challenges faced by all industries [1]. To overcome these problems, many manufacturers are interested in the development of eco-friendly materials using green renewable resources as feedstocks [2]. These concepts have reached a critical mass of interest in the printing industry due to pressure from consumers, environmental groups, and government agencies. All printing manufacturers must demonstrate environmental responsibility by using green raw materials and sustainable manufacturing processes. To achieve these goals, reduction of the adverse environmental impact from printing inks is an important aspect.

Various vegetable oils and their by-products have been used as sustainable feedstocks in preference to petroleum products, especially for alkyd resin synthesis, due to increased awareness of environmental concerns [3]. Alkyd resins are unsaturated oil-modified polyesters synthesized from polycondensation reactions between polycarboxylic acids and polyalcohol in the presence of various traditional vegetable oils such as soybean oil [4-7], castor oil [8,9], linseed oil [10], sunflower oil [1,7,11,12], and coconut oil [13]. Since alkyd resins were first introduced many decades ago they have enjoyed consistent annual growth and received great importance because of low processing cost, availability of raw materials, and ease of applications $[1,14]$. These resins are widely used in various coating industries as binders, paints, inks, and varnish [15]. In the ink industry, they offer excellent properties including good gloss, adhesion, flexibility, wettability of the pigment, and various other kinds of anti-resistance [5]. However, a major obstacle in the commercialization of alkyd resins from edible vegetable oils is their high production cost 
http://wjst.wu.ac.th

due to the demand for human consumption. Reducing the cost of feedstocks is necessary for long-term commercial viability. One way to reduce the cost of feedstocks is to use less expensive raw materials, such as waste frying oils and non-edible vegetable oils.

Large quantities of waste frying oil from households and food industries are available throughout the world. This waste oil usually contains many harmful decomposition products occurring from oxidation, hydrolysis, and polymerization [16-18]. Management of this waste poses a significant challenge, and unregulated disposal contaminates water and land resources. Various approaches have been studied to utilize this waste in a way that is not harmful to the environment, such as feedstock for biodiesel production [16,17,19,20]. From an economic point of view, waste oil possesses many advantages, because of low cost and ease of availability in significant quantities as an unutilized byproduct. Waste frying oil could be a promising alternative raw material for the manufacture of alkyd resins. With proper utilization of waste oil as chemical feedstocks, environmentally threatening problems can be turned into green economical benefits.

Despite extensive research focusing on using plant-based oils for the manufacture of alkyd resins [1,4-13], lack of knowledge exists regarding the use of waste oil as feedstock. In a previous study, we successfully prepared ink vehicles from waste frying soybean oil via the heat polymerization technique [21]. Here, we synthesized environmentally friendly alkyd-based ink vehicles from waste frying oil and compared their compositions and properties against commercial black printing inks to evaluate their potential use.

\section{Materials and methods}

\section{Materials}

Waste frying soybean oil was collected from small shops after being used several times for frying purposes. Virgin soybean oil was purchased from Thai Vegetable Oil Public Co. Ltd., Bangkok, Thailand. Activated bleaching clay (Wonder Earth NK 309) was a gift from Bornnet Corporation Co. Ltd., Bangkok, Thailand. Glycerol (99.8\%) and phthalic anhydride (99.9 \%) were purchased from UnivarAjax Finechem, Australia. Calcium oxide $(\mathrm{CaO} ; 99.9 \%)$ was purchased from Fluka, Switzerland. Carbon black and commercial alkyd inks were supplied by Kulwong Co. Ltd., Bangkok, Thailand. Drier (6 \% Manganese Lin-All® PI Drier) was purchased from Borchers Americas Incorporated, USA. QualikydTM QA-130-70, a commercial soybean oil modified long oil alkyd resin, was supplied by Qualimer Corporation Co. Ltd., Thailand. All other chemicals were used directly without further purification.

\section{Preparation of alkyd resin}

Prior to synthesis, the waste oil was filtered to eliminate any residues and then decolorized following previous methods [21]. Briefly, the filtrated oil was gently stirred for $2 \mathrm{~h}$ in the presence of $5 \%$ $\mathrm{w} / \mathrm{w}$ activated bleaching clay at $80{ }^{\circ} \mathrm{C}$ under a nitrogen atmosphere. After that, the mixture was centrifuged and filtered to remove the bleaching clay. Scheme 1 illustrates the approach to synthesize alkyd resin by alcoholysis with glycerol to form monoglyceride and then esterification with phthalic anhydride to form alkyd resin, according to the modified method reported previously [22]. Briefly, $100 \mathrm{~g}$ of oil and $20 \mathrm{~g}$ of glycerol were added to the Dean-Stark vessel. The mixture was stirred at $500 \mathrm{rpm}$ and then heated to $210^{\circ} \mathrm{C}$ under a nitrogen atmosphere followed by addition of $0.05 \mathrm{~g}$ of calcium oxide as a catalyst. The temperature was then raised to $230{ }^{\circ} \mathrm{C}$ and the mixture was maintained at this temperature for $2 \mathrm{~h}$ until a sample (1 part) was soluble in ethanol (2 parts). The mixture was cooled to $150{ }^{\circ} \mathrm{C}$ and a certain amount of phthalic anhydride was added. The mixture was reheated to $230{ }^{\circ} \mathrm{C}$ and maintained at this condition for $5 \mathrm{~h}$ before being cooled to room temperature and stored in an airtight container. In order to control the viscosity of the obtained vehicles compared with the commercial alkyd, the mole ratios of hydroxyl to anhydride were kept at 1:0.6, 1:0.7, and 1.0.8, respectively. Additionally, the virgin oil alkyd resin was prepared by fixing the mole ratio of hydroxyl to anhydride at 1:0.7. Amounts of all materials used in this step are presented in Table 1. 


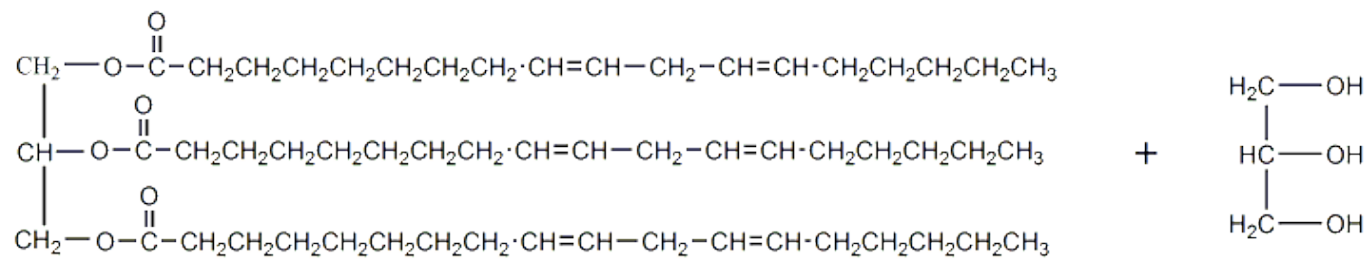

Waste frying oil

Glycerol

$230{ }^{\circ} \mathrm{C}, 2 \mathrm{~h}$

$\mathrm{CaO}$

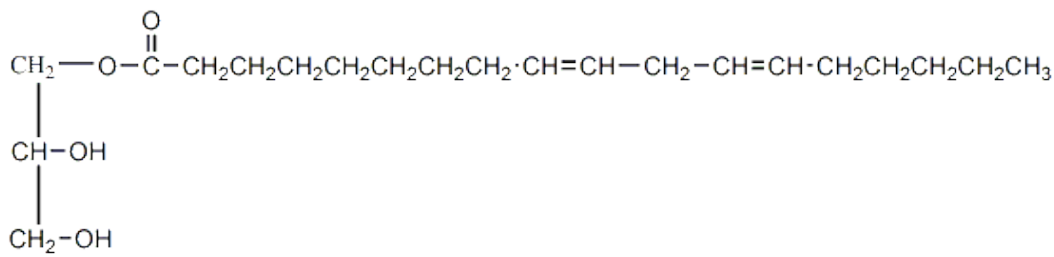

Monoglyceride

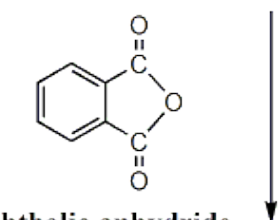

$230{ }^{\circ} \mathrm{C}, 5 \mathrm{~h}$

Phthalic anhydride

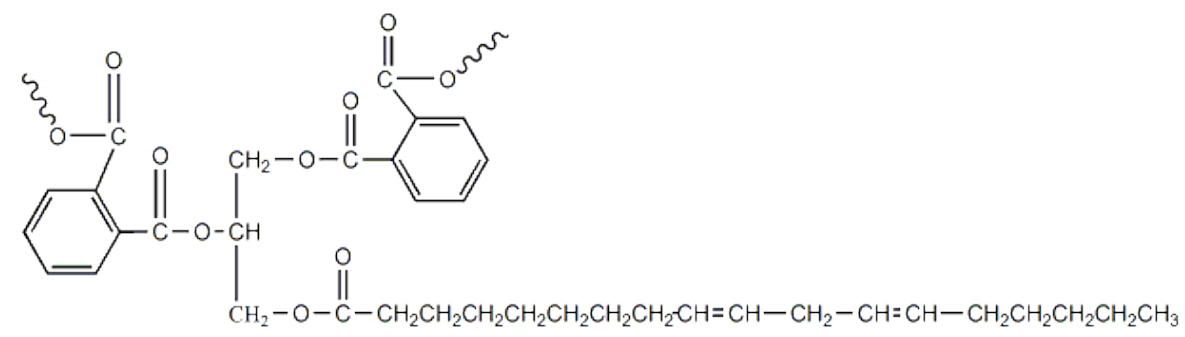

Alkyd resin

Scheme 1 Alcoholysis and esterification reaction of oil-modified alkyd resin. 
http://wjst.wu.ac.th

Table 1 Formulations of the as-prepared alkyd ink vehicles synthesized from waste oil and virgin oil with various phthalic anhydride weight ratios.

\begin{tabular}{|c|c|c|c|c|c|}
\hline \multirow{3}{*}{ Formula } & \multirow{3}{*}{$\begin{array}{l}\text { Hydroxyl to } \\
\text { anhydride } \\
\text { mole ratio }\end{array}$} & \multicolumn{4}{|c|}{ Weight ratios of reactants } \\
\hline & & \multicolumn{2}{|c|}{ Hydroxyl } & \multirow{2}{*}{$\begin{array}{c}\text { Anhydride } \\
\text { Phthalic anhydride (g) }\end{array}$} & \multirow{2}{*}{$\mathrm{CaO}(\mathrm{g})$} \\
\hline & & Oil (g) & Glycerol (g) & & \\
\hline Alkyd-1 & $1: 0.6$ & 100 & 20 & 28.96 & 0.05 \\
\hline Alkyd-2 & $1: 0.7$ & 100 & 20 & 33.79 & 0.05 \\
\hline Alkyd-3 & $1: 0.8$ & 100 & 20 & 38.62 & 0.05 \\
\hline Virgin oil alkyd & $1: 0.7$ & 100 & 20 & 33.79 & 0.05 \\
\hline
\end{tabular}

\section{Preparation of black printing inks}

To evaluate possible use of the as-prepared vehicles as printing ink binders, black printing inks were prepared by mixing the as-prepared vehicles with $10 \% \mathrm{w} / \mathrm{w}$ of carbon black powder. The mixtures were stirred vigorously at 1,000 rpm for $1 \mathrm{~h}$ and then ground with a 3-roll mill until a uniform dispersion was achieved. The obtained printing inks were collected and kept in a vacuum bottle until required for further investigation. To study printing appearance, the formulated printing inks were mixed with $0.5 \% \mathrm{w} / \mathrm{w}$ of drier in order to increase the drying ability and then screen printed on white paper. The obtained printing paper was dried at room temperature for $4 \mathrm{~h}$. The printing properties were then compared with those of virgin oil alkyd ink and commercial alkyd ink.

\section{Characterization}

Physical properties of waste frying oil, as well as the as-prepared alkyd resins, were examined with regard to iodine value (IV), acid value (AV), molecular weight $\left(\mathrm{M}_{\mathrm{w}}\right)$, viscosity, and color. Iodine value was determined following a modified method based on ASTM D1959, while the acid value was calculated based on ASTM D1980. Molecular weight was determined by gel permeation chromatography (GPC: Shimadzu Class-VP, Shimadzu Scientific Instruments, Columbia, MD, USA). Viscosities of the as-prepared alkyd resins and the obtained printing inks were measured using a Brookfield CAP 2000+ Series Viscometer (Ametek Brookfield, Middleboro, MA, USA). Color was determined by comparison with the color of standard Gardner solutions, while chemical structures were characterized using a Nicolet FT-IR spectrophotometer (Model Thermo Nicolet Nexus 670, Nicolet Instruments Inc., Madison, WI, USA) and ${ }^{1} \mathrm{H}-\mathrm{NMR}$ spectroscopy (Varian Unity Inova $500 \mathrm{MHz}$ NMR, Georgia, USA).

To study potential uses of the as-prepared alkyd vehicles as printing inks, preliminary properties of various formulated black printing inks were investigated. Pigment dispersion was measured by fineness of grind gauge (Grindometer: Precision Gauge \& Tool Co., Dayton, Ohio, USA). Ink tack was measured by a tack tester (Model IGT Tack Tester 450; IGT Testing System Inc., IL, USA) based on ASTM D4361. Ink rub resistance was measured by an ink rub tester (Model Digital Ink Rub Tester 10-18-010001; TMI Group of Companies, New Castle, DE, USA) based on ASTM D5264. Rub resistance was defined as the unwanted transfer of ink from the printed page to another surface. Amount of rub off was reported as percent blackness of a stain that results by pulling a tissue weighted with $6.89 \times 10^{3} \mathrm{~Pa}$ pressure over the surface of a printed sheet. Blackness densities were measured with a Macbeth Color-Eye 7,000 Spectrophotometer, type CE7000 (X-Rite, Inc., Grand Rapids, MI, USA) and calculated from the following equation:

$\%$ Blackness $=\frac{\% R_{\text {tissue }}-\% R_{\text {rub stain }}}{\% R_{\text {tissue }}} \times 100$,

where $\% \mathrm{R}$ is percent reflection at $560 \mathrm{~nm}$. Blackness of less than $6 \%$ after $2 \mathrm{~h}$ of testing was considered characteristic of ink with good rub off resistance [23]. Furthermore, water resistances were also analyzed 
http://wjst.wu.ac.th

based on ISO 2836 . Briefly, a $20 \times 50 \mathrm{~mm}^{2}$ sample of the print was covered with 2 saturated sheets of filter paper, a $1 \mathrm{~kg}$ mass was placed on the top, and the sample was left at $23 \pm 2{ }^{\circ} \mathrm{C}$ for $24 \mathrm{~h}$.

\section{Results and discussion}

\section{Properties of waste frying oil}

The waste frying oil was first characterized; properties are illustrated in Table 2. The IV value which measures the degree of unsaturation of waste oil was $91 \mathrm{~g} \mathrm{I}_{2} / 100 \mathrm{~g}$ of sample. The AV value, which represents the amount of free fatty acid occurring from hydrolysis of triglycerides, was $0.48 \mathrm{mg} \mathrm{KOH} / \mathrm{g}$ of sample. Molecular weight $\left(\mathrm{M}_{\mathrm{w}}\right)$ and viscosity of waste oil were $1,041 \mathrm{~g} / \mathrm{mol}$ and $95 \mathrm{cP}$, respectively, while the color was light brown, with Gardner scale of 4 . For virgin oil, typical IV and AV values ranged from $85-110 \mathrm{~g} \mathrm{I}_{2} / 100 \mathrm{~g}$ and $0.37-0.75 \mathrm{mg} \mathrm{KOH} / \mathrm{g}$, respectively [24], with typical molecular weight (Mw) $885.58 \mathrm{~g} / \mathrm{mol}$ and viscosity $54.3 \mathrm{cP}$ at $23.9^{\circ} \mathrm{C}[24,25]$. The color of virgin soybean oil was light yellow, with Gardner scale of 1.5 [21]. Alteration of its properties corresponded to the change of triglyceride molecules when subjected to high temperature in the presence of air and moisture via hydrolysis, oxidation, and polymerization to form dimeric, trimeric, and oligomeric structures [18], which resulted in an increase in molecular weight and decrease in the iodine value of the oil after frying. Increase in the acid value was possibly due to hydrolysis of the oil after frying to produce free fatty acids, while color of the waste frying oil was darker due to the presence of nonvolatile substances resulting from oxidation reactions after frying $[18,26]$.

Table 2 Properties of waste frying oil.

\begin{tabular}{cccccc}
\hline Sample & $\begin{array}{c}\text { IV value } \\
(\mathbf{g ~ I} / \mathbf{1 0 0} \mathbf{g} \text { oil) }\end{array}$ & $\begin{array}{c}\text { AV value } \\
(\mathbf{m g ~ K O H} / \mathbf{g})\end{array}$ & $\begin{array}{c}\mathbf{M}_{\mathbf{w}} \\
(\mathbf{g} / \mathbf{m o l})\end{array}$ & $\begin{array}{c}\text { Viscosity } \\
\text { (cP) }\end{array}$ & $\begin{array}{c}\text { Color } \\
\text { (Gardner) }\end{array}$ \\
\hline Waste frying oil & 91 & 0.48 & 1,041 & 95 & 4 \\
\hline
\end{tabular}

To verify the chemical structure of waste oil, FT-IR and ${ }^{1} \mathrm{H}-\mathrm{NMR}$ were performed. Figure 1a illustrates the FT-IR spectrum of waste oil, which provided the characteristic absorption peaks coinciding with the general evidence of triglyceride structure, including absorption intensity of $\mathrm{C}=\mathrm{C}-\mathrm{H}$ stretching of aliphatic fatty acid at $3,009 \mathrm{~cm}^{-1}, \mathrm{C}-\mathrm{C}-\mathrm{H}$ stretching at 2,926 and $2,855 \mathrm{~cm}^{-1}, \mathrm{C}=\mathrm{O}$ stretching of ester linkages at $1,746 \mathrm{~cm}^{-1}$ and $\mathrm{C}=\mathrm{C}$ stretching of aliphatic fatty acid at $1,655 \mathrm{~cm}^{-1}$ [27]. Figure $1 \mathbf{b}$ illustrates the ${ }^{1} \mathrm{H}-\mathrm{NMR}$ spectrum of waste oil, which also showed relatively well-defined characteristics of triglyceride structures. Characteristic peaks at $0.87-0.91 \mathrm{ppm}$ corresponded to protons of the terminal methyl group $\left(-\mathrm{CH}_{3}\right)$, while peaks at $1.26-1.40 \mathrm{ppm}$ represented protons of all internal $\mathrm{CH}_{2}$ groups in the fatty acid chains. Peaks at $1.55-1.65 \mathrm{ppm}$ indicated protons of $\mathrm{CH}_{2}$ groups attached next to and above the terminal methyl group. Peaks at $2.0-2.1 \mathrm{ppm}$ identified allylic protons $(=\mathrm{C}-\mathrm{C}-\mathrm{H})$ at $2.25-2.35 \mathrm{ppm}$ for protons of ester groups and at $2.70-2.80 \mathrm{ppm}$ for $\mathrm{CH}_{2}$ of double allylic protons. Characteristic peaks at $4.10-4.30 \mathrm{ppm}$ were for protons of glyceride moiety. Peaks of vinylic protons $(=\mathrm{C}-\mathrm{H})$ moiety appeared at $5.30-5.40 \mathrm{ppm}$. 
a)

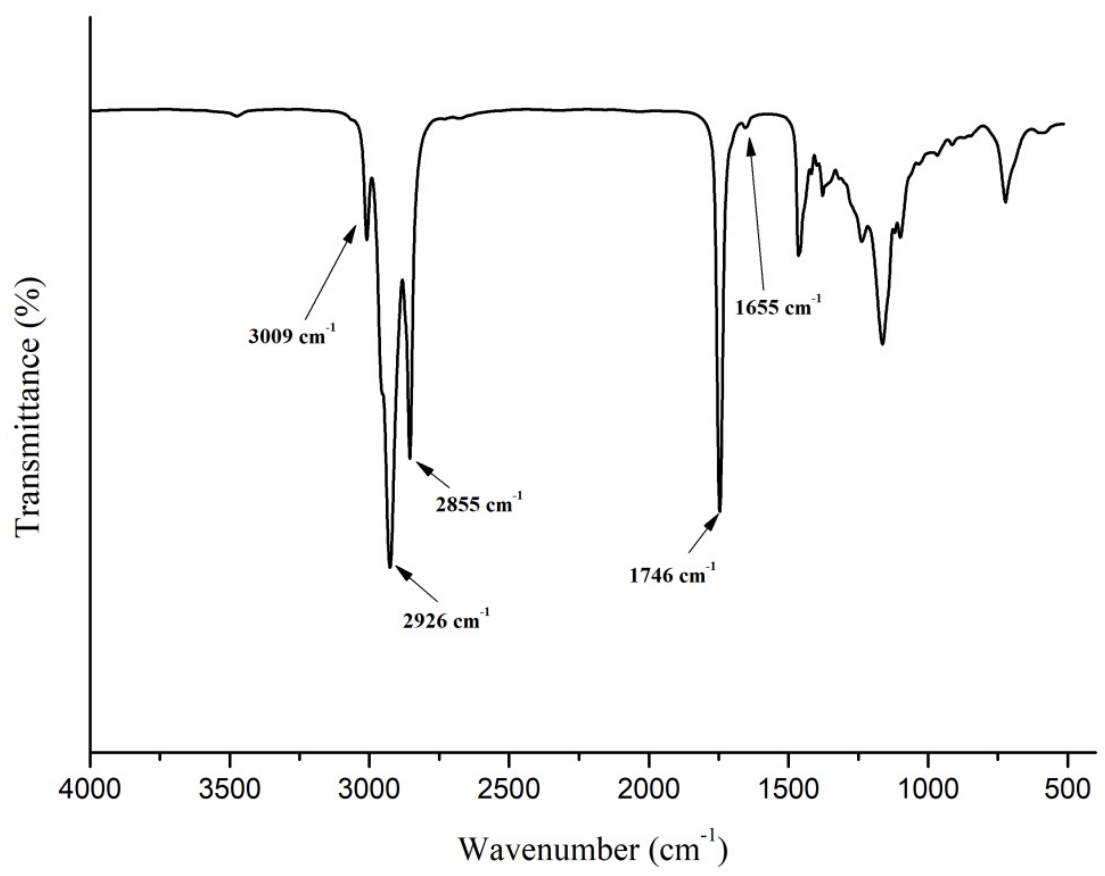

b)
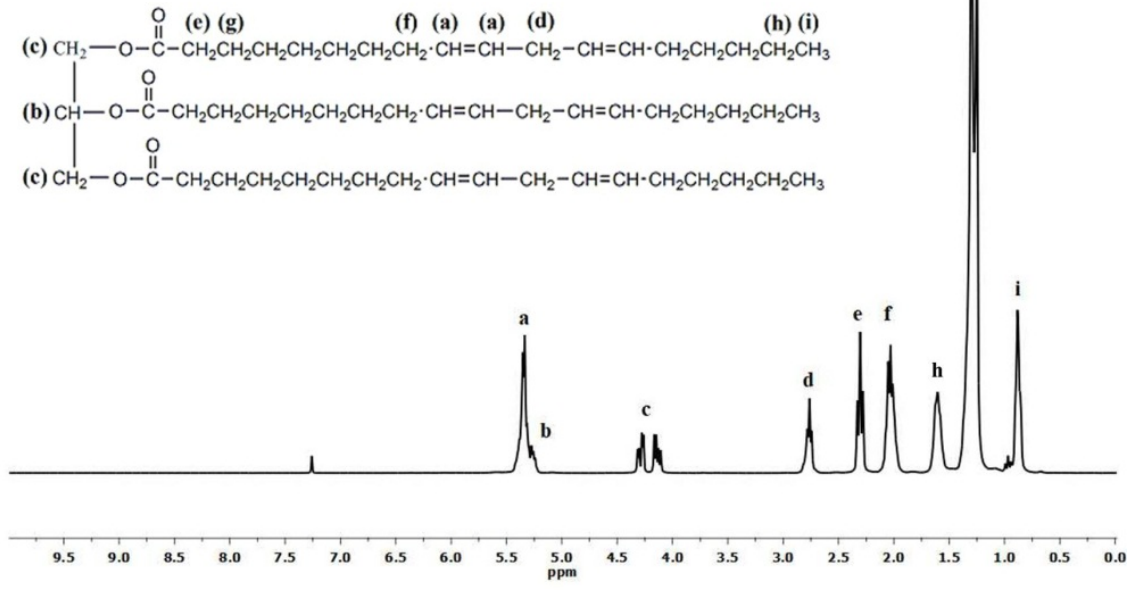

Figure 1 a) FT-IR spectrum and b) ${ }^{1} \mathrm{H}-\mathrm{NMR}$ spectrum of waste frying oil. 
http://wjst.wu.ac.th

\section{Chemical structure of as-prepared monoglyceride}

To verify the chemical structure of the as-prepared monoglyceride, FT-IR and ${ }^{1} \mathrm{H}-\mathrm{NMR}$ were performed. Figure 2a illustrates the FT-IR spectrum of the as-prepared monoglyceride, with characteristic absorption peaks similar to the spectrum of waste oil, except for a broad characteristic absorption peak in the range of 3,200 $-3,400 \mathrm{~cm}^{-1}$ attributed to the presence of hydroxyl groups. For the ${ }^{1} \mathrm{H}-\mathrm{NMR}$ spectrum (Figure 2b), new signal intensities of methylinic proton (-CH-OH) of glycerol moiety also appeared in the region of $3.8-4.0 \mathrm{ppm}$ and protons associated with the hydroxyl groups in the region of $3.5-3.8 \mathrm{ppm}$.

a)

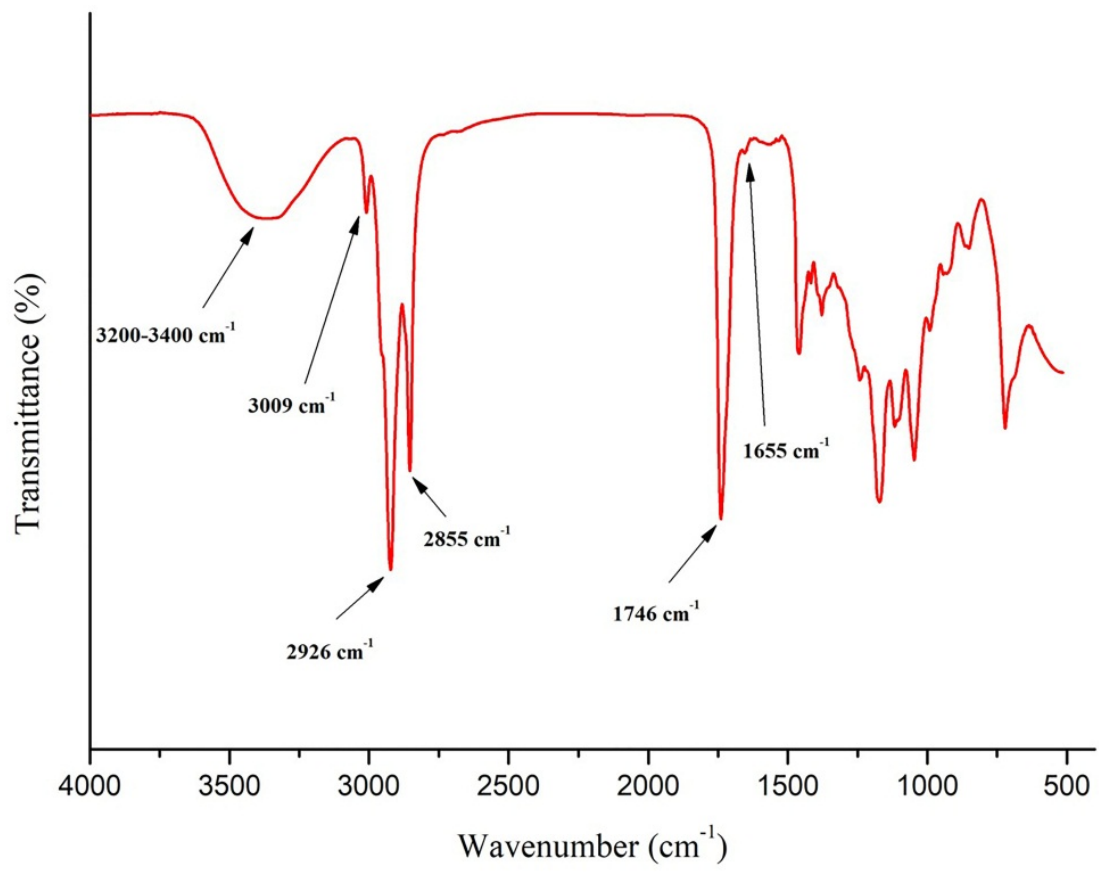


b)

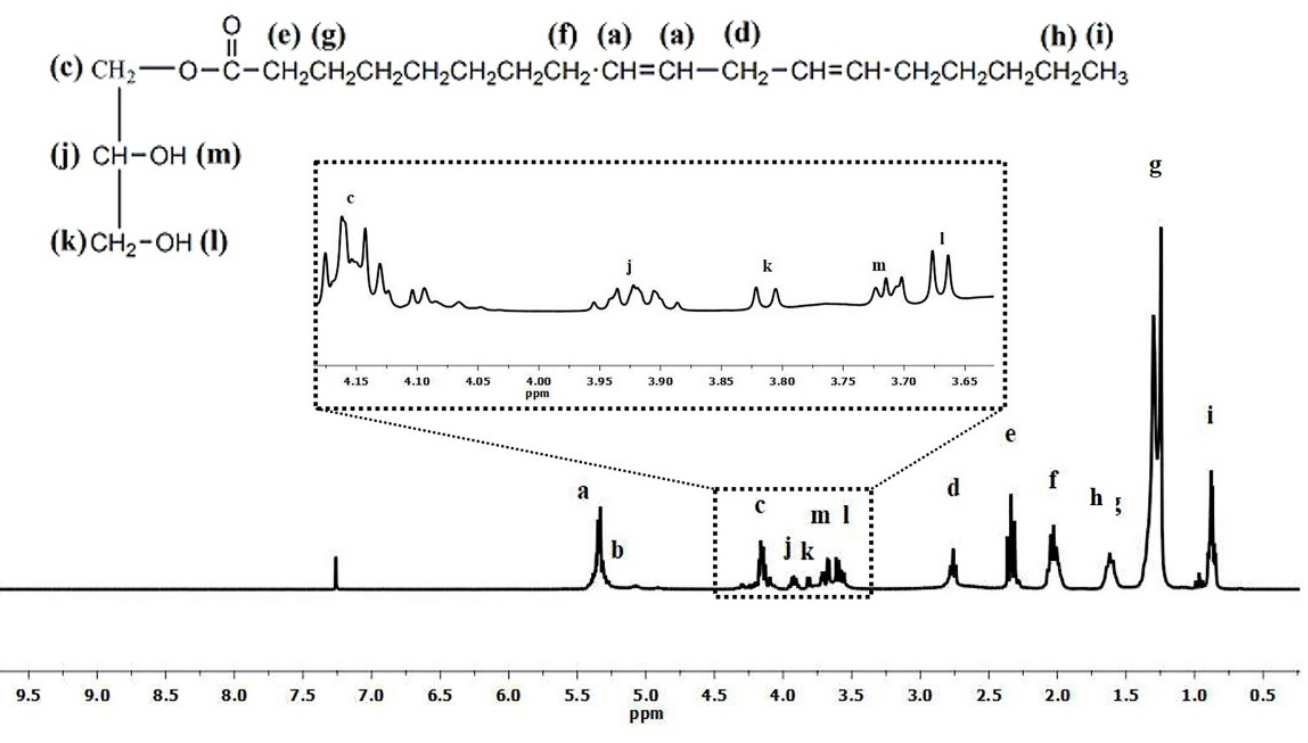

Figure 2 a) FT-IR spectrum and b) ${ }^{1} \mathrm{H}-\mathrm{NMR}$ spectrum of the as-prepared monoglyceride.

\section{Properties of alkyd-based ink vehicles}

Ink vehicles are fluid parts of inks that transport and bind pigments onto substrates. These make up the major components of inks as primary determinants of flow characteristics and properties. Table 3 illustrates the properties of the as-prepared alkyd ink vehicles synthesized from various weight ratios of phthalic anhydride compared with those of virgin oil and commercial alkyd ink vehicles. The AV values of the alkyd ink vehicles gradually increased as the weight ratio of phthalic anhydride increased and ranged from 9.25 to $10.81 \mathrm{mg} \mathrm{KOH} / \mathrm{g}$ of sample. However, the virgin oil alkyd ink vehicle and commercial alkyd ink vehicle had a lower AV value than vehicles derived from waste oil. AV value is an important aspect of alkyd resin because resin with a high AV value forms a coating very slowly or not at all [28].

Table 3 Properties of the as-prepared alkyd ink vehicles synthesized from waste oil compared with those of virgin oil and commercial alkyd ink vehicles.

\begin{tabular}{cccccc}
\hline Formula & $\begin{array}{c}\text { AV value } \\
(\mathbf{m g ~ K O H} / \mathbf{g})\end{array}$ & $\begin{array}{c}\text { Viscosity } \\
(\mathbf{P})\end{array}$ & $\begin{array}{c}\mathbf{M}_{\mathbf{w}} \\
(\mathbf{g} / \mathbf{m o l})\end{array}$ & $\begin{array}{c}\text { Polydispersity } \\
\text { (PDI) }\end{array}$ & $\begin{array}{c}\text { Color } \\
\text { (Gardner) }\end{array}$ \\
\hline Alkyd-1 & 9.25 & 8.6 & 1,621 & 1.39 & 7 \\
Alkyd-2 & 9.53 & 19.5 & 1,864 & 1.47 & $8+$ \\
Alkyd-3 & 10.81 & 34.9 & 2,352 & 1.61 & $9+$ \\
Virgin oil alkyd & 6.50 & 15.5 & 1,720 & 1.42 & 5 \\
Commercial alkyd & 5.30 & 17.6 & 4,717 & 18.37 & 5 \\
\hline
\end{tabular}


http://wjst.wu.ac.th

Viscosities of the alkyd ink vehicles showed ratio dependence on the phthalic anhydride contents due to higher conversion of the acidic monomers. Viscosity of Alkyd-1 prepared from 1:0.6 mole ratios was 8.6 poises, and this increased to 19.5 and 34.9 poises as the amount of phthalic anhydride increased to 1:0.7 (Alkyd-2) and 1:0.8 (Alkyd-3) mole ratios, respectively. Viscosity of the obtained resin increased as the condensation process between hydroxyl groups of polyols and carboxyl groups of the anhydride increased, in line with increasing molecular weight of the reaction product. Molecular weights and molecular weight distributions of the obtained resins are shown in Table 3. Alkyd-1 had a molecular weight of $1,621 \mathrm{~g} / \mathrm{mol}$, and this increased to $1,864 \mathrm{~g} / \mathrm{mol}$ for Alkyd-2 and 2,352 g/mol for Alkyd-3 with narrow molecular weight distribution. However, molecular weights of all synthesized alkyd resins were lower than the commercial resin, as a result of diverse reactants and conditions used to synthesize the resin. Regarding other parameters, color of the obtained resins was darker than the virgin oil resin and commercial resin. Characteristics of all synthesized alkyd resins were slightly different from the commercial resin, due to disparate components and types of reactants used in alkyd resin synthesis.

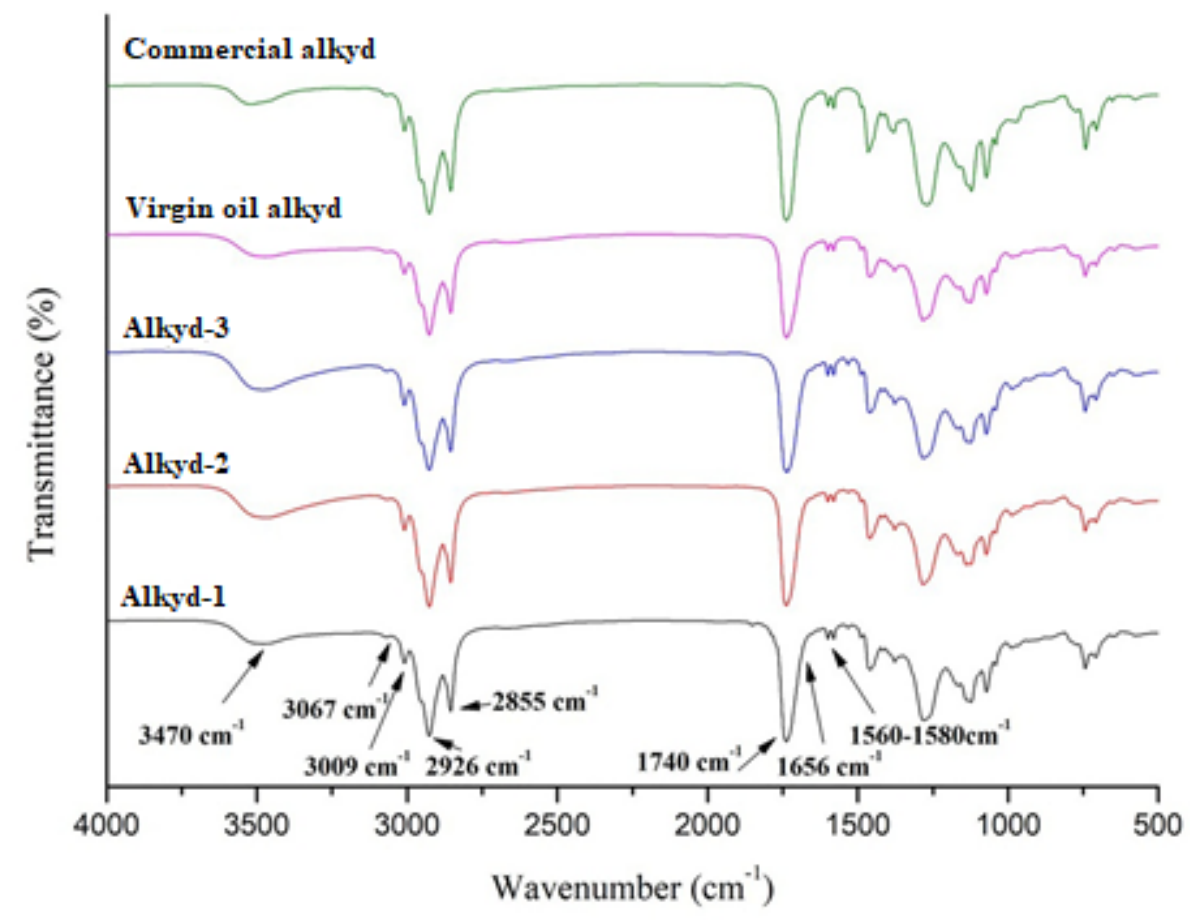

Figure 3 FT-IR spectra of the as-prepared alkyd ink vehicles derived from waste oil with various phthalic anhydride weight ratios compared with those of virgin oil and commercial alkyd ink vehicles.

Chemical structures of the as-prepared alkyd ink vehicles were confirmed by FT-IR spectra and ${ }^{1} \mathrm{H}$ NMR spectra. FT-IR spectra (Figure 3) of the as-prepared vehicles showed relatively well-defined characteristics of waste oil, except for the shift of absorption peaks, representing $\mathrm{C}=\mathrm{O}$ stretching of ester linkages at $1,740 \mathrm{~cm}^{-1}$, which indicated some modification around the carbonyl group. The peak at 3,067 $\mathrm{cm}^{-1}$ corresponded to $\mathrm{C}=\mathrm{C}-\mathrm{H}$ stretching, while peaks at $1,560-1,580 \mathrm{~cm}^{-1}$ corresponded to $\mathrm{C}=\mathrm{C}$ stretching of aromatic rings. The broad peak at $3,470 \mathrm{~cm}^{-1}$ confirmed the presence of unreacted hydroxyl groups; however, this absorption peak decreased as the amount of phthalic anhydride increased, indicating an incremental esterification reaction of alkyd resin (see detailed characterization in supplementary data). ${ }^{1} \mathrm{H}-\mathrm{NMR}$ spectra, as shown in Figure 4, also showed relatively well-defined characteristics of triglyceride structure, as previously mentioned, except for the presence of aromatic 
protons of phthalic anhydride appearing at $7.18-7.35 \mathrm{ppm}$. New signal intensities of methylinic proton ($\mathrm{CH}-\mathrm{OH}$ ) of glycerol moiety appeared in the region of $3.8-4.0 \mathrm{ppm}$ and the proton associated with the hydroxyl groups in the region of $3.5-3.8 \mathrm{ppm}$. These results supported the alkyd structure formed from waste oil.

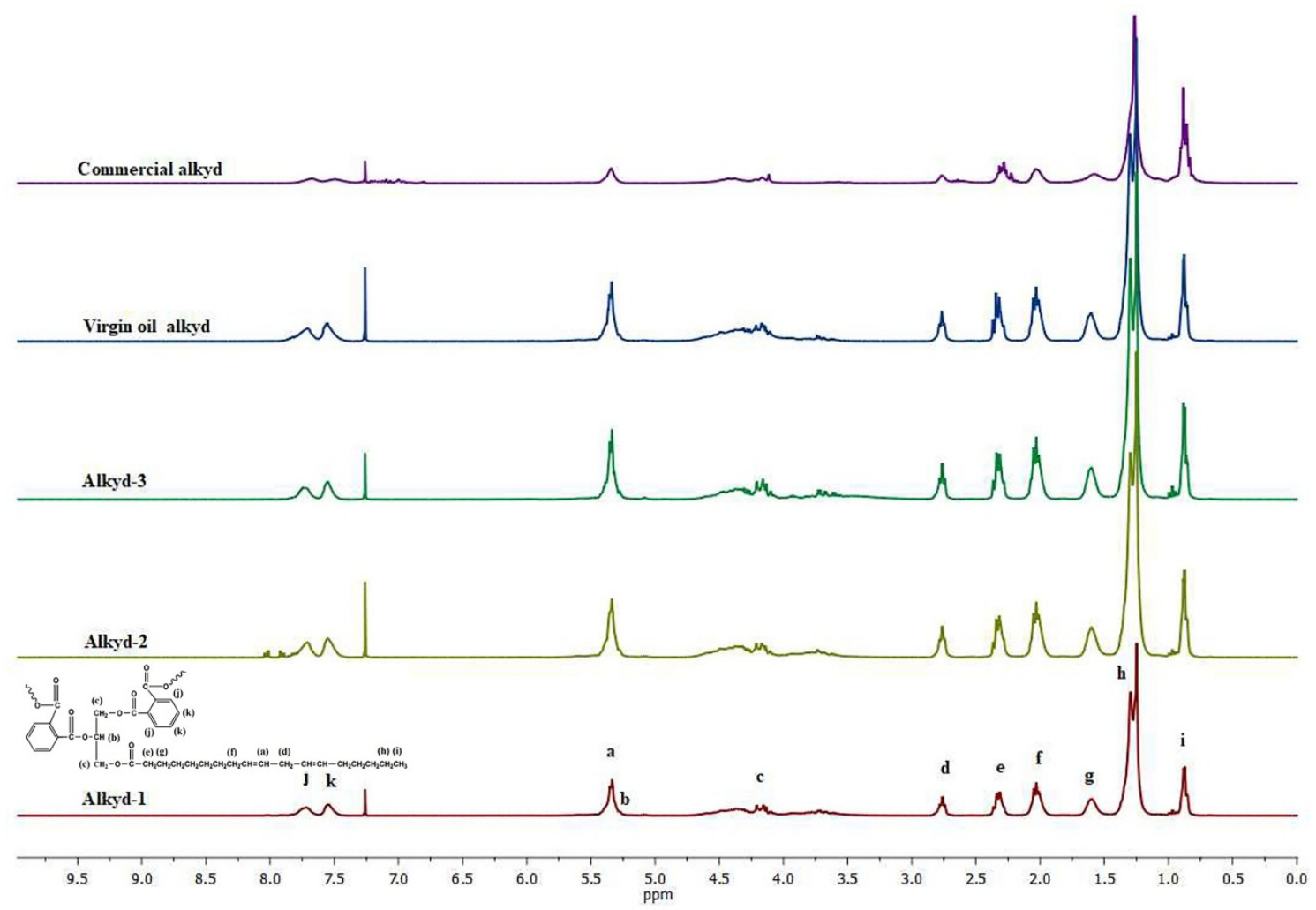

Figure $4{ }^{1} \mathrm{H}-\mathrm{NMR}$ spectra of the as-prepared alkyd ink vehicles derived from waste oil with various phthalic anhydride weight ratios compared with those of virgin oil and commercial alkyd ink vehicles.

\section{Properties of as-prepared black printing inks}

To study potential uses as printing inks, preliminary properties of various formulated black printing inks were measured. Commercially, viscosities of paste inks, such as letterpress, lithographic, and screen printing inks, range at about 5 - 50 poises, whereas viscosities of liquid inks, such as gravure and flexographic inks, range at $0.05-5.0$ poises. The tack values of paste inks are normally about $2.6-4.8$ $\mathrm{g} \cdot \mathrm{m}$, and not important for liquid inks [23]. Table 4 illustrates the properties of black printing inks from as-prepared alkyd ink vehicles with $10 \% \mathrm{w} / \mathrm{w}$ of carbon black powder compared with the virgin oil alkyd ink and commercial alkyd ink vehicles. Viscosities of the obtained printing inks showed strong dependence on viscosity of the as-prepared ink vehicles. Viscosity of printing ink prepared from Alkyd-1 was 12.2 poises, and this increased to 27.5 poises for Alkyd-2 and 45.1 poises for Alkyd-3. For tack values, results indicated the strong effect of viscosity of the ink vehicles on their tack properties. Tack values increased from $3.2 \mathrm{~g} \cdot \mathrm{m}$ for printing ink prepared from Alkyd-1 to $6.9 \mathrm{~g} \cdot \mathrm{m}$ for Alkyd-2 and $9.7 \mathrm{~g} \cdot \mathrm{m}$ for Alkyd-3. These tack values met or exceeded the range of standard paste inks. However, ink viscosities and ink tack values of all as-prepared printing inks differed from the commercial alkyd ink, possibly due to differences in components and types of reactants used to produce commercial alkyd ink vehicles. 
http://wjst.wu.ac.th

Table 4 Properties of black printing inks prepared from waste oil alkyd ink vehicles with $10 \% \mathrm{w} / \mathrm{w}$ of carbon black compared with those of virgin oil alkyd and commercial alkyd ink vehicles.

\begin{tabular}{cccccc}
\hline Formula & $\begin{array}{c}\text { Ink viscosity } \\
\mathbf{( P )}\end{array}$ & $\begin{array}{c}\text { Ink tack } \\
(\mathbf{g} \cdot \mathbf{m})\end{array}$ & $\begin{array}{c}\text { Blackness } \\
\mathbf{( \% )}\end{array}$ & $\begin{array}{c}\text { Particle fineness } \\
(\boldsymbol{\mu} \mathbf{m})\end{array}$ & $\begin{array}{c}\text { Water } \\
\text { Tolerance }\end{array}$ \\
\hline Alkyd-1 & 12.2 & 3.2 & 4.61 & $<7$ & Excellent \\
Alkyd-2 & 27.5 & 6.9 & 4.93 & $<7$ & Excellent \\
Alkyd-3 & 45.1 & 9.7 & 5.75 & $<10$ & Excellent \\
$\begin{array}{c}\text { Virgin oil } \\
\text { alkyd }\end{array}$ & 25.2 & 6.0 & 4.13 & $<10$ & Excellent \\
$\begin{array}{c}\text { ommercial } \\
\text { alkyd }\end{array}$ & 25.1 & 6.4 & 3.51 & $<10$ & Excellent \\
\hline
\end{tabular}

Results for rub resistance were analyzed in terms of percent blackness (\% Blackness), which indicates the amount of transfer ink from the tested printed sample to white paper. The lower valued ink was judged to be significantly superior in rub resistance. Our obtained inks had rub resistance values ranging from $4.61-5.75 \%$, slightly higher than rub resistance of the virgin oil alkyd ink $(4.13 \%)$ and commercial alkyd ink (3.51\%). However, suitable tack and rub resistance values of the formulated inks could be achieved by adding appropriate additives such as waxes [29]. For particle fineness, all formulated inks provided properties which compared with the virgin oil alkyd ink and commercial alkyd ink. For water tolerance test, all formulated inks showed excellent water resistance. Printed samples of the formulated black inks are shown in Table 5. Black text printed from waste oil-based printing inks was clear and similar to the virgin oil alkyd ink and commercial alkyd ink. All results showed that waste frying oil could be a promising alternative raw material for the manufacture of black printing inks. However, further investigation regarding printing ink production based on waste frying oil is necessary. 
http://wjst.wu.ac.th

Table 5 Samples of formulated black printing inks from various waste oil alkyd ink vehicles with $10 \%$ w/w of carbon black compared with those of virgin oil alkyd and commercial alkyd ink vehicles.
Formula
Printed samples

Alkyd-1
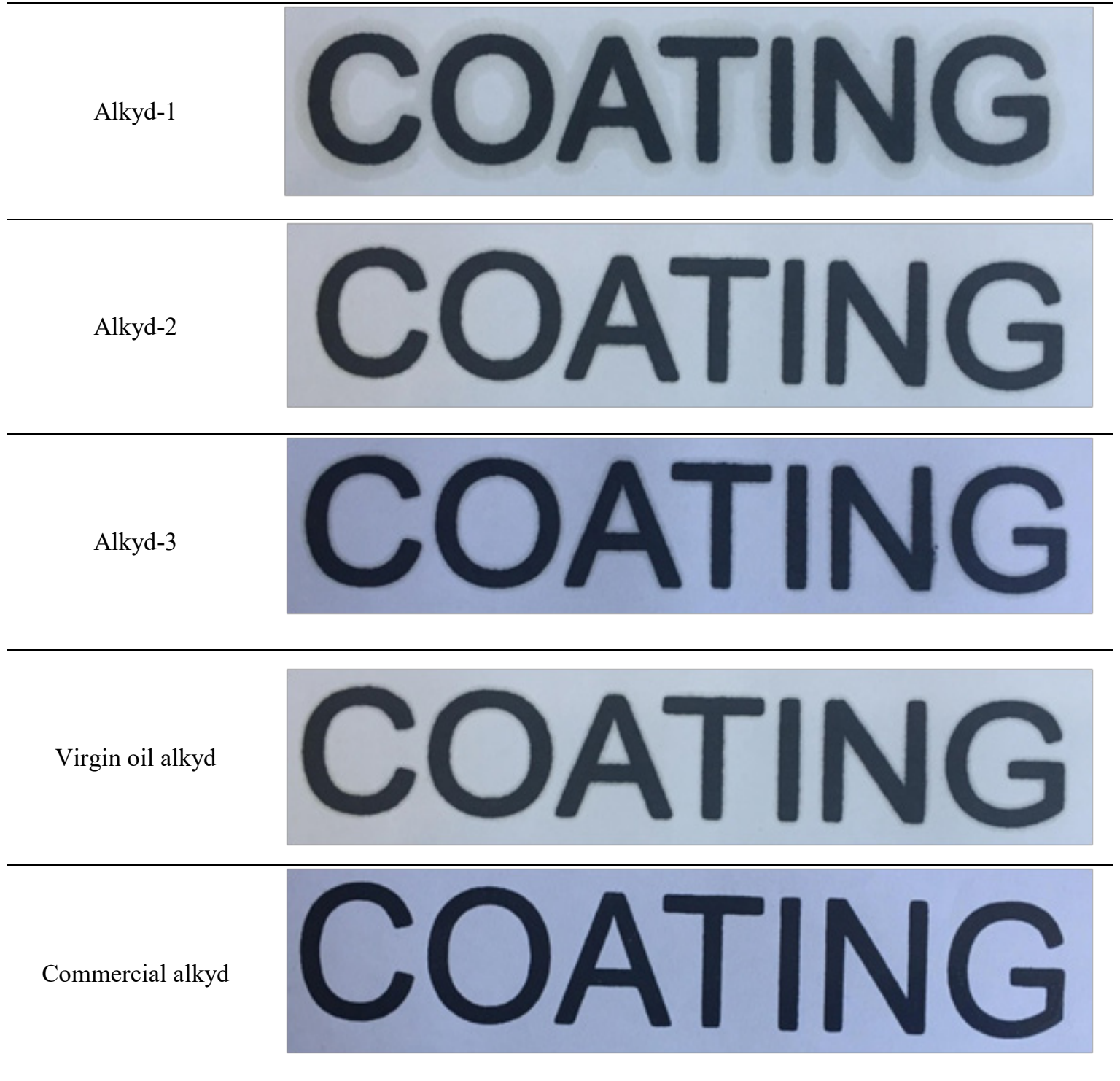

\section{Conclusions}

We successfully synthesized waste oil-based alkyd ink vehicles. Their black printing inks showed all the preliminary desired properties. Alkyd resins were synthesized by alcoholysis with glycerol and esterification with phthalic anhydride. Results showed that the amount of phthalic anhydride played an important role in the enhancement of resin properties. The vehicles were also completely compatible with carbon black for formulating black inks. The obtained formulated inks acquired satisfying printing ink properties which might be suitable for making inks with a variety of printing applications. Performance of 
http://wjst.wu.ac.th

waste oil-based alkyd ink vehicles was found to be comparable with virgin oil resin and commercial resin. Our results indicated that waste frying oil, a by-product from households and food industries, has potential as an economic raw material for producing environmentally friendly, lower-cost ink vehicles.

\section{Acknowledgements}

The authors would like to acknowledge the Department of Materials Science, Faculty of Science, Chulalongkorn University, and the Petroleum and Petrochemical College, Chulalongkorn University, for instrument support. The authors also gratefully acknowledge (1) The Royal Government of Thailand Scholarship 2562, and (2) a grant from the International Research Integration: Research Pyramid, Ratchadaphiseksomphot Endowment Fund (GCURP_58_02_63_01) of Chulalongkorn University, for financial support of this research.

\section{References}

[1] PP Chiplunkar and AP Pratap. Utilization of sunflower acid oil for synthesis of alkyd Resin. Prog. Org. Coat. 2016; 93, 61-7.

[2] M Alam, D Akram, E Sharmin, F Zafar and S Ahmad. Vegetable oil based eco-friendly coating materials: A review article. Arab. J. Chem. 2014; 7, 469-79.

[3] S Pramanik, K Sagak, BK Konwar and N Karak. Synthesis, characterization and properties of a castor oil modified biodegradable poly(ester amide) resin. Prog. Org. Coat. 2012; 75, 569-78.

[4] BA Kyenge, BA Anhwange, JT Ageh and GO Igbum. Comparative analysis of soybean seed oil modified alkyd resin and epoxidized soybean seed oil modified alkyd resin. Int. J. Modern Org. Chem. 2012; 1, 66-71.

[5] X Zheng, L Yang and K Wang. Synthesis and characterization of alkyd resin based on soybean oil polyols. Adv. Mat. Res. 2011; 239-242, 1721-4.

[6] JU Ezeagba, UJM Ikezu and EO Iloh. Formation of an oil paint using alkyd resin from soybean oil. World Appl. Sci. J. 2014; 32, 83-7.

[7] JS Ling, IA Mohammed, A Ghazali and M Khairuddean. Novel poly(alkyd-urethane)s from vegetable oils: Synthesis and properties. Ind. Crops Prod. 2014; 52, 74-84.

[8] DH Solomon and JJ Hopwood. Molecular weight distribution in alkyd resins part II. Castor oil and hydrogenated castor oil alkyds. J. Appl. Polym. Sci. 1966; 10, 993-1009.

[9] O Saravari and S Praditvatanakit. Preparation and properties of urethane alkyd based on a castor Oil/Jatropha oil mixture. Prog. Org. Coat. 2013; 76, 698-704.

[10] DH Solomon and JD Swift. The influence of catalysts on the glycerolysis of linseed oil. J. Oil Col. Chem. Assoc. 1966; 49, 915-27.

[11] S Aydin, H Akçay, E Özkan, FS Güner and AT Erciyes. The effects of anhydride type and amount on viscosity and film properties of alkyd resin. Prog. Org. Coat. 2004; 51, 273-79.

[12] MA Mutar and NMA Hassan. Synthesis and characterization of new alkyd resins (Short, Medium and Long) based on sunflower oil and Linoleic acid as binder for paints. Inter. J. Chem. Petro. Tech. 2017; 7, 1-16.

[13] RH Wholf. 1968, Coconut Oil Modified Alkyd Resins and Copolymers Thereof with an Alkyl Acrylate, US Patent 3374194.

[14] KA Ibrahim, KA Abu-sbeih, I Al-Trawneh and L Bourghli. Preparation and characterization of alkyd resins of Jordan valley tomato oil. J. Polym. Environ. 2014; 22, 553-8.

[15] SFM Mustafa, SN Gan and R Yahya. Synthesis and characterization of novel alkyds derived from palm oil based polyester resin. Asian J. Chem. 2013; 25, 8737-40.

[16] J Cvengroš and Z Cvengrošová. Used frying oils and fats and their utilization in the production of methyl esters of higher fatty acids. Biomass Bioenerg. 2004; 27, 173-81.

[17] MG Kulkarni and AK Dalai. Waste cooking oils - An economical source for biodiesel: A review. Ind. Eng. Chem. Res. 2006; 45, 2901-13.

[18] E Choe and DB Min. Chemistry of deep-fat frying oils. J. Food Sci. 2007; 72, R77-R86. 
http://wjst.wu.ac.th

[19] AB Chhetri, KC Watts and MR Islam. Waste cooking oil as an alternate feedstock for biodiesel production. Energies 2008; 1, 3-18.

[20] DP Patil, VG Gude, HK Reddy, T Muppaneni and S Deng. Biodiesel production from waste cooking oil using sulfuric acid and microwave irradiation processes. J. Environ. Prot. 2012; 3, 7.

[21] S Phunphoem, P Supaphol and O Saravari. Soy ink vehicles from waste frying oils for green printing technology. J. Eng. Appl. Sci. 2016; 11, 2326-30.

[22] VC Patel, J Varughese, PA Krishnamoorthy, RC Jain, AK Singh and M Ramamoorty. Synthesis of alkyd resin from Jatropha and rapeseed oils and their applications in electrical insulation. J. Appl. Polym. Sci. 2008; 107, 1724-9.

[23] SZ Erhan, MO Bagby and HW Cunningham. Vegetable oil-based printing inks. J. Am. Oil Chem. Soc. 1992; 69, 251-6.

[24] KL Konge and AS Sabnis. Synthesis and characterization of soybean oil based biodiesel under optimal Sonication power. Res. J. Eng. Sci. 2013; 2, 26-32.

[25] H Noureddini, BC Teoh and LD Clements. Viscosities of vegetable oils and fatty acids. J. Am. Oil Chem. Soc. 1992; 69, 1189-91.

[26] U Mehta and B Swinburn. A review of factors affecting fat absorption in hot chips. Crit. Rev. Food Sci. Nutr. 2001; 41, 133-54.

[27] NA Gomez, R Abonia, H Cadavid and IH Vargas. Chemical and spectroscopic characterization of a vegetable oil used as dielectric coolant in distribution transformers. J. Braz. Chem. Soc. 2011; 22, 2292-303.

[28] H Nosal, J Nowicki, M Warzała, E Nowakowska-Bogdan and M Zarębska. Synthesis and characterization of alkyd resins based on Camelina sativa oil and polyglycerol. Prog. Org. Coat. 2015; 86, 59-70.

[29] J Izdebska and S Thomas. Printing on Polymers: Fundamentals and Applications. $1^{\text {st }}$ (Ed.). William Andrew Press, New York, 2016, p. 92-9. 